\title{
Genetic variability of Indonesian Oryctes rhinoceros nudivirus (OrNV) as genus of Alphanudivirus
}

\author{
SAT RAHAYUWATI ${ }^{1, \vartheta}$, YAYI MUNARA KUSUMAH ${ }^{1}$, SUDHARTO PRAWIROSUKARTO ${ }^{2}$, DADANG ${ }^{1}$, \\ TEGUH SANTOSO ${ }^{1, \vee \varphi}$ \\ ${ }^{1}$ Department of Plant Protection, Faculty of Agriculture, Institut Pertanian Bogor. J1. Kamper, Dramaga, Bogor 16680, West Java, Indonesia. \\ Tel.: +62-251-8629364, Fax.: +62-251-8629362, `email: sat_rahayuwati.yahoo.com, ${ }^{\text {}}$ teg.santoso@gmail.com \\ ${ }^{2}$ PT. Astra Agro Lestari Tbk. Jl. Pulau Ayang Raya Blok OR-1, Kawasan Industri Pulogadung Jakarta Timur 13930, Jakarta, Indonesia
}

Manuscript received: 8 January 2020. Revision accepted: 16 April 2020.

\begin{abstract}
Rahayuwati S, Kusumah YM, Prawirosukarto S, Dadang, Santoso T. 2020. Genetic variability of Indonesian Oryctes rhinoceros nudivirus (OrNV) as genus of Alphanudivirus. Biodiversitas 21: 2047-2055. Oryctes rhinoceros nudivirus (OrNV) is known as a successful classical biological control agent. Recent reports have revealed differences in pathogenicity among OrNV isolates, with correlation suspected between virus virulence and genetic variability. The aim of the research is to study the genetic variability of OrNV isolates based on the DNA polymerase (DNA pol) gene and their phylogenetic relationship with Genus Alphanudivirus. Oryctes rhinoceros (Coleoptera: Scarabaeidae) as an OrNV host were collected from Sumatra, Belitung, Java, Kalimantan, and Sulawesi. Primers were designed to amplify complete gene of DNA pol. Sequencing, phylogenetic, and investigate genetic diversity scores were used to determine variability at nucleotide level. Five primers successfully amplified the entire DNA pol gene. Genetic variability of OrNV was high, from nine isolates found eight genetically different. Isolates could be divided into two groups of genetic diversity: high and low. High genetic diversity of OrNV supposed as an old population that occupied Sundaland and Wallacean paleogeography at first appearance in Miocene Era until early Pliocene 5 Mya. New population of OrNV had low genetic diversity were travel cross-island that supposed to correlate with oil palm plantation development and the genetic drift. The benefit information of the OrNV genetic variability is as preliminary guideline for virulence test. OrNV is a member of Nudiviridae family, Genus Alphanudivirus, and at recent moment they consist of eight species. Alphanudivirus infect Coleoptera, Diptera, Hemiptera and Orthoptera order that soil as immature niche may explain their closely related taxa.
\end{abstract}

Keywords: DNA polymerase gene, genetic variability, Nudiviridae family, Oryctes rhinoceros nudivirus, OrNV

\section{INTRODUCTION}

Indonesia has a biological wealth of virus, Oryctes rhinoceros nudivirus (OrNV), from the Nudiviridae family. OrNV was discovered by Huger (1966) as part of an exploration of Oryctes rhinoceros (Coleoptera; Scarabaeidae) natural enemies in south-east Asia as endemic areas. OrNV is known as successful classical biological control that has been used to manage $O$. rhinoceros in the Pacific (Huger 2005; Huger 1966). Unfortunately, $O$. rhinoceros is important pest in Indonesian and Malaysian. These beetles attacking young oil palms less than four years during replanting (Bedford 2014). Adults are the most troublesome during the establishment of young palm, and the damage has increased with current extensive replanting schemes (Ramle et al. 2005). Minister Agriculture of RI regulation number 18/permentan/KB.330/5/2016 about oil palm replanting program, entail to chipped oil palm trunks with thickness $5-20 \mathrm{~cm}$ of $45-60^{\circ}$ angle direction. Prohibited of land clearing by burning also stated in UU RI no 32-year 2009 about environmental protection and management. Chipped trunk with zero burnings was good regulation although still as optimum habitat for the breeding immature stage of $O$. rhinoceros in 9 until 18 months after felling and chipping (Abidin et al. 2014). O. rhinoceros behavior in coconut slightly different than adult attacks the tree throughout the year. The adults population fluctuates influenced by breeding sites such as coconut trunks, cow dung, sawdust, husks, piles of organic matter (Salim and Hosang 2013).

Nudiviridae is a nonoccluded Baculovirus that has been reported to infect a wide range of insect orders (Huger and Krieg 1991). The lack of an occlusion body as reported by Wang et al. (2007a) justifies its classification as a naked virus that has been termed Nudivirus. Nudivirus has a genome size of 95-228 kb, rod-shaped virions, circular dsDNA, and it replicates in the host nucleus (Wang et al. 2007b). There was a proposal in 2013 to make Nudivirus into a new family, Nudiviridae, with two genus members Alphanudivirus and Betanudivirus (Jehle et al. 2013). By 2019, the genera had grown to become four-plus Gammanudivirus, Deltanudivirus with the members of this family infecting not only insects but also crustaceans (Holt et al. 2019; Bézier et al. 2015). Gammanudivirus is suggested to be a genus that specializes in infecting diverse aquatic crustacean taxa (Holt et al. 2019). Alphanudivirus is the most growing genus of Nudivirus as a result of viral metagenomics study. Viral metagenomics is the study of viral genetic material recovered directly from environmental samples. As sequencing technology continues to develop causing an increasingly large 
database. These databases provide important information that can be used for study of viral taxonomy, evolutionary relationship, genome organization, finding organism, finding genes and its pathways (Segata et al. 2011; Simmonds et al. 2017). By using these metagenomic databases, four species of Alphanudivirus has been found infected Drosophila melanogaster (Diptera: Drosophilidae): Mauternbach nudivirus, Kallithea nudivirus, Tomelloso nudivirus, Esparto nudivirus (Webster et al. 2015).

OrNV has not been optimally used as an $O$. rhinoceros biological control. It is hoped that success in the use of OrNV in the Pacific will indicate similar success for rhinoceros management in Indonesia. OrNV has different geographical pathogenicity (Moslim et al. 2011) that could be favorable in virus development. The pathogenicity of viruses can be used to control the insect host population (Federici and Maddox 1996); a relationship is also suspected between virus virulence and its genetic variability. The genetic variability of OrNV in Indonesia has not yet been reported.

Nucleotide sequences provide much in the way of phylogenetic information. Systematic studies have shown that some genes are visibly better than others for reconstructing evolutionary relationships at particular levels of divergence (Simon et al. 1994). The DNA changes exhibit a regular pattern that could be formulated as a tree using a mathematical model. Using this model, it is possible to formulate the DNA change and compare it with distantly related taxa (Sutrisno 2006). DNA pol is one of the genes used to construct phylogenetic of virus (Federici and Bigot 2003). All known types of virus DNA that infect animal cells encode their own DNA pol (Braithwaite and Ito 1993). DNA pol was likely present in the earliest virus ancestors. This suggestion is supported by the observation that phylogenies constructed by viral polymerase match with viral taxonomic classifications (Shackelton and Holmes 2004).

The aim of this research is, therefore, to look for the genetic variability of Indonesian OrNV based on DNA pol gene and then mine the relationship information between other Genus Alphanudivirus that have been reported by National Center for Biotechnology Information (NCBI).

\section{MATERIALS AND METHODS}

\section{Sampling}

Oryctes rhinoceros were taken from single point in predetermined provinces (Table 1). The sampling and midgut collection was carried out between January and April 2018. Individual midguts were placed in a sterilized Eppendorf tube for storage at $-20^{\circ} \mathrm{C}$ at the Insect Pathology Laboratory of IPB University, Bogor, Indonesia.

\section{Primer design}

Primers were designed to amplify the complete OrNV DNA pol gene with isolate Ma07 from Malaysia with accession number EU747721.1 as a primer reference (Wang et al. 2008). DNA pol gene nucleotides were submitted to the online primer design www.idtdna.com. Each primer was manipulated up to its end with $\mathrm{C}$ or $\mathrm{G}$ nucleotide and then ordered to First Base Asia Sdn Bhd.

\section{DNA isolation and PCR (Polymerase Chain Reaction)}

The Quick-DNA miniprep plus kit from Zymo Research was used for DNA extraction (Jackson et al. 2010). The PCR thermal cycle was based on the Dream Taq Green PCR master mix protocol from Thermo Scientific. The PCR master mix was prepared in $50 \mu \mathrm{L}$ containing $25 \mu \mathrm{L}$ Dream Taq Green PCR master mix, $1 \mu \mathrm{M}$ forward and reverse primer, $10 \mathrm{pg}-1 \mu \mathrm{g}$ templates, and up to $50 \mu \mathrm{L}$ of nuclease-free water.

The primer annealing temperature was determined using the TM calculator by Thermo Fisher Scientific. Annealing temperature was optimized by increased $4^{\circ} \mathrm{C}$ and decreased $2^{\circ} \mathrm{C}$ from temperature suggestion. Temperature yielded the thickest DNA band selected as annealing temperature for PCR reaction.

Amplified polymerase sequences were visualized with $1.5 \%$ agarose. DNA was stained with $2 \mu \mathrm{L}$ peqGreen DNA and RNA dye from peqlab, a VWR company. Electrophoresis was conducted with TBE $1 \mathrm{x}$ buffer at 100 volts for 30 minutes. The DNA bands were observed with UV light and documented (Jackson et al. 2010).

\section{Sequencing and data analysis to investigate the nucleotide diversity and its phylogeny}

The amplified PCR products with size approximately $700 \mathrm{bp}$ of primer OrNV 200F/R and product with size approximately1500 bp of Primer OrNV1 F/R, OrNV2 F/R, OrNV3 F/R, OrNV4 F/R were sent to First Base Asia Sdn Bhd to be sequenced. Batch assembly of multiple DNA sequences was automatically undertaken by DNA Sequence Assembler V5.15.0 (32 bit) (2013). The sequences were visually checked for correction. DNA pol gene was identified using the BLAST program in NCBI, and the start and stop codons of the DNA pol gene were determined using the NCBI ORF finder: https: //www.ncbi.nlm.nih.gov/orffinder. DNA pol gene was deposited to NCBI for accession number requesting.

A phylogenetic tree was constructed using NCBI's recent deposit of complete gene DNA pol of Alphanudivirus and an outgroup was Heliothis zea Nudivirus 1 (HzNV1), Genus Betanudivirus (Table 2). The DNA pol sequences were aligned with clustal W multiple alignments and find the sequence identity matrix with BioEdit V 5.0.7 (Hall 1999). The alignment was trimmed in order to minimize end gaps. Second align use Clustal X for fasta format output (Thompson et al. 1997) and then processed for maximum likelihood phylogeny tree construction by MEGA 7 (Kumar et al 2016). Best DNA model was Tamura 3 parameter (Nei and Kumar 2000) and the tree branch integrity was tested using Bootstrap (Pellock et al. 1996) with 1000 replicates. The DnaSP program (Rozas et al. 2017) was used to dig information about genetic variability of OrNV DNA pol gene like number of haplotypes, variable sites $(\mathrm{S})$, number mutation (Eta), nucleotide diversity (Pi), and haplotype (gene) diversity (Hd). 
Table 1. Sampling site including location, type of sample, commodity, counterpart, and GPS coordinate

\begin{tabular}{|c|c|c|c|}
\hline Location & $\begin{array}{l}\text { Individual of } \\
\text { Oryctes rhinoceros }\end{array}$ & Commodity and counterpart & GPS coordinate \\
\hline Marihat Baris, Siantar Sub-district, & Adult $=57$ & Oil palm; Indonesian Oil Palm & $2.9223,99.0894$ \\
\hline Simalungun District, North Sumatra & Larvae $=50$ & Research Institute (IOPRI) & \\
\hline Kalianta Estate, Rokan Hulu District, Riau & $\begin{array}{l}\text { Adult }=61 \\
\text { Larvae }=50\end{array}$ & Oil palm; IOPRI & $0.465870,100.820694$ \\
\hline Sijuk Village, Bangka-Belitung Islands & $\begin{array}{l}\text { Adult }=50 \\
\text { Larvae }=50\end{array}$ & $\begin{array}{l}\text { Coconut; undergraduate student of } \\
\text { IPB Univesity }\end{array}$ & $-2.55847,107.74773$ \\
\hline Parungkuda Sub-district, Sukabumi District, & Adult $=50$ & Coconut; Indonesian Industrial & $-6.844,106.7526$ \\
\hline West Java & Larvae $=50$ & $\begin{array}{l}\text { Beverage Crops Research Institute } \\
\text { (IIBCRI) }\end{array}$ & \\
\hline Bulumanis Lor, Margoyoso Sub-district, Pati & Adult $=60$ & Coconut; Dinas Kehutanan dan & $-6.608368,111.068438$ \\
\hline District, Central Java & Larvae $=50$ & Perkebunan, Central Java Province & \\
\hline Rubung Buyung, Cempaga, East & Adult $=74$ & Oil palm; PT. Bumitama Gunajaya & $-2.19719,113.06786$ \\
\hline Kotawaringin District, Central Kalimantan & & Agro (BGA) & \\
\hline $\begin{array}{l}\text { Pundu, Cempaga Hulu, East Kotawaringin } \\
\text { District, Central Kalimantan }\end{array}$ & Larvae $=50$ & & $-1.97657,113.10685$ \\
\hline $\begin{array}{l}\text { Babulu Darat, Babulu Sub-district, Penajam } \\
\text { Paser Utara District, East Kalimantan }\end{array}$ & Larvae $=50$ & Oil palm; farmer & $-1.495287,116.406840$ \\
\hline $\begin{array}{l}\text { Kumasari, Sarudu Sub-district, Mamuju } \\
\text { Utara District, West Sulawesi }\end{array}$ & Adult $=54$ & $\begin{array}{l}\text { Oil palm; PT Surya Lestari 1, Astra } \\
\text { Agro Group }\end{array}$ & $-1.701959,119.367979$ \\
\hline $\begin{array}{l}\text { Tammarunang, Duripoku Sub-district, } \\
\text { Mamuju Utara District, West Sulawesi }\end{array}$ & Larvae $=50$ & Oil palm; IOPRI outlet Mamuju & $-1.648731,119.411832$ \\
\hline $\begin{array}{l}\text { Beteleme Village, Lembo Sub-district, } \\
\text { Morowali District, Central Sulawesi }\end{array}$ & $\begin{array}{l}\text { Adult }=3 \\
\text { Larvae }=17\end{array}$ & Oil palm; IOPRI outlet Morowali & $-2.1396,121.2839$ \\
\hline
\end{tabular}

Table 2. National Center for Biotechnology Information (NCBI) accession number of DNA polymerase gene as source of phylogenetic tree. The isolates with bold words were samples in this research. As out group of the tree was Heliothis zea nudivirus 1 (HzNV1)

\begin{tabular}{ll}
\hline Isolate's name & $\begin{array}{c}\text { NCBI } \\
\text { accession } \\
\text { number }\end{array}$ \\
\hline Oryctes rhinoceros nudivirus (OrNV) Riau01 & $\begin{array}{l}\text { MK241543.1 } \\
\text { OrNV Philippines PV505 }\end{array}$ \\
OH015832.2 \\
OrNV Sulteng01 & MK241541.1 \\
OrNV Malaysia Ma07 & EU747721.1 \\
OrNV Kaltim01 & MK241540.1 \\
OrNV Jabar01 & MK241544.1 \\
OrNV Belitung01 & MK241547.1 \\
OrNV Kalteng01 & MK241548.1 \\
OrNV Jateng01 & MK241545.1 \\
OrNV Sulbar01 & MK241546.1 \\
Tomelloso Nudivirus Dros EU28 (Tomelloso NV) & MK241542.1 \\
Drosophila innubila nudivirus (DiNV) & MF966379.1 \\
Mauternbach Nudivirus (Mauternbach NV) & MG969167.1 \\
Kallithea Nudivirus (Kallithea NV) & KP714105.1 \\
Esparto Nudivirus (Esparto NV) & KY608910.1 \\
Nilaparvata lugens endogenous nudivirus (NINV) & KJ566528.1 \\
Gryllus bimaculatus nudivirus (GbNV) & NC_009240.1 \\
Heliothis zea nudivirus 1 (HzNV1) & AF451898.1 \\
\hline
\end{tabular}

\section{RESULTS AND DISCUSSION}

\section{Preparation for phylogenetic construction}

OrNV infect both larvae and adult of $O$. rhinoceros. OrNV replicate in nucleus of midgut and fat body both of larvae and adults (Huger 1966, Huger 2005). OrNV infection in adult is simply detected by dissection and examining their midgut. Midgut of infected adult is swollen, white color, approximately $4 \mathrm{~mm}$ diameter, and have milky contents. Midgut uninfected adult contains brown, narrow (1 $\mathrm{mm}$ diameter) with clear contents (Crawford and Zelazny 1990). Larvae with severe OrNV infection also have prominent appearance: shiny, beige, waxen, increased turgidity, and their rectum was completely prolapsed (Huger 2005).

OrNV DNA was taken from individual adults of $O$. rhinoceros which belong infected feature as mentioned above. The substantial DNA extraction from single host was to ensure purely of the OrNV isolate. It could be any mixed infection of different isolates in one spot of $O$. rhinoceros habitat, although mixed infections themselves were rare (Crawford and Zelazny 1990). Investigate signature adaptation gene of Nudivirus by Hill and Unckless (2018) was also using single individual of Drosophila innubila (Diptera: Drosophilidae).

The Quick-DNA miniprep plus kit from Zymo Research yielded a reasonably good quality of total DNA from midgut with obvious symptoms of OrNV infection. The DNA showing a relatively high concentration and purity. Quick-DNA miniprep is a DNA purification method that uses a matrix column made of silica, glass, or diatoms. Nucleic acid is absorbed by the column during the purification process. Pure DNA is then elucidated using buffer elution (Tan and Yiap 2009). DNA concentration from infected midgut was rise significantly by crushing, enzyme digestion at $55^{\circ} \mathrm{C}$ for 3 hours, and pre-warmed buffer elution at $65^{\circ} \mathrm{C}$. 
A total of five primers were designed to amplify the complete gene sequence of OrNV DNA pol (Table 3). The amplicons have different sizes of $650 \mathrm{bp}$ and $1500 \mathrm{bp}$. The primer amplicons overlap with each other. The primer order from the start to the stop codon of DNA pol gene was primer 200F/200R, OrNV4F/OrNV4R, OrNV3F/OrNV3R, OrNV2F/OrNV2R, and OrNV1F/OrNV1R. The five primers designed had a high ability to detect OrNV infection in both adults and larvae of $O$. rhinoceros. The primers are quite sensitive to detect an early infection of the OrNV by extraction of midgut tissue. Thick PCR band was produced from extraction of white swollen midgut diameter of $4 \mathrm{~mm}$ while thin PCR band was resulted from not swollen midgut diameter $1 \mathrm{~mm}$. These positive PCR results were strongly correlated with visual disease symptoms in $O$. rhinoceros adult also reported by Richard et al. (1999). Sequencing requires sufficient DNA concentration. Sequencing for thin PCR band sample, comprised two PCR steps aimed at increasing the DNA pol gene amplicon. The first solution carried out for PCR processes was then applied as a DNA template for the second PCR.

\section{Oryctes rhinoceros nudivirus (OrNV) variability}

Genetic variability that is caused by spontaneous mutations makes the evolution of OrNV possible (Hall et al. 1984). Spontaneous mutations occur by errors in DNA replication, but the polymerase gene can control production of point mutation by selected correct polymerization or removed of incorrect bases using exonuclease (Hall et al. 1984). DNA pol genes of virus are usually essential genes that they are evolved closely with the virus and thus reflect their evolution (Pellock et al. 1996). The mutations that propagate are the ones that increase survival. Investigation of the genetic variability basically looks at tiny changes in microevolution.

The main task of an OrNV DNA pol gene is to ensure complete copy of its genome. Since OrNV replicates in the nucleus of infected host cells (Wang and Jehle 2009), OrNV does not need to encode their own DNA pol. Genome replication and mRNA synthesis of OrNV depends on host cell machinery (Choi 2012). OrNV has double-stranded (dsDNA) (Wang and Jehle 2009) that replicate their genomes using DNA-dependent DNA polymerases (or called DNA polymerases) and transcribe
mRNA using DNA-dependent RNA polymerases (or called RNA polymerases) (Choi 2012).

The evolution can be presented as a phylogenetic tree whose leaves correspond to extant species and the nodes to extinct ancestors. Phylogenetic analysis is usually carried out with DNA sequences to interpret closely related species rather than protein (Wolf et al. 2002). In the study of OrNV evolution, the phylogenetic tree uses its nucleotides. The phylogenetic tree tells exactly how OrNV from Indonesia related to others, and how recently or distantly with other particular Alphanudivirus genus (Figure1).

Kobayashi and Somowiyarjo (1995) mentioned that there are only slight differences in the pattern of restriction for EcoRI and HindIII fragments from Indonesian isolates. They suggested that there are many of OrNV isolates from Indonesia. DnaSP program (Rozas et al. 2017) could show how high levels of variabilities of Indonesian OrNV (Table 4).

Number for haplotype of Indonesian OrNV were eight: haplotype 1 (isolate Sumut01), haplotype 2 (Sulteng01 and Riau01), haplotype 3 (Sulbar01), haplotype 4 (Kaltim01), haplotype 5 (Kalteng01), haplotype 6 (Jateng01), haplotype 7 (Jabar01), and haplotype 8 (Belitung01). Haplotype refers to a group of genes within an organism that was inherited together from a single parent (Nature 2005). It was supposed that Sulteng01 and Riau01 isolate of OrNV have the same parental origin although both were far apart for $2205 \mathrm{~km}$.

Genetic variability within population mainly estimated using score of haplotype diversity ( $\mathrm{Hd}$ ) and nucleotide diversity (Pi) (de Jong et al. 2011). The meaning of haplotype diversity or gene diversity is probability that two randomly sampled alleles are different. While nucleotide diversity is the average number of nucleotide differences per site in pairwise comparisons among DNA sequences. Based on the definition by de Jong et al. (2011) show that randomly sampled alleles of Indonesian OrNV were different one with another, except OrNV isolate Sulteng01 and Riau01 (Table 4). Four groups of tests showed a maximum Hd score (1.00) which means these maximum scores for gene diversity. One group test (Sulteng01 and Riau01) was without Hd score because two isolates were no gene diversity. As mentioned above, Sulteng01 and Riau01 supposed from single parental.

Table 3. Primers for amplifying complete gene of Oryctes rhinoceros nudivirus (OrNV) DNA polymerase

\begin{tabular}{|c|c|c|c|c|}
\hline No & Name & Sequence & GC content $(\%)$ & The amplicon length (bp) \\
\hline \multirow[t]{2}{*}{1} & OrNV1 F & 5'-GGA GAG GAT GTG TGT GAC TTT-3' & 47.6 & 1504 \\
\hline & OrNV1 R & 5'-CGC GCA ACA TTC GGT TAT AC-3' & 50.0 & \\
\hline \multirow[t]{2}{*}{2} & OrNV2 F & 5'-GTT TCA CTG ACC GAC AAG CTA-3' & 47.6 & 1509 \\
\hline & OrNV2 R & 5'-GGC CGA AAG GTC TCC ATT AT-3' & 50.0 & \\
\hline \multirow[t]{2}{*}{3} & OrNV3 F & 5'-GAA GAA CTC CGC TAG ATA CGT TAA-3' & 41.7 & 1516 \\
\hline & OrNV3 R & 5'-GAC CCT CCC ATA TCA CGA TTA C-3' & 50.0 & \\
\hline \multirow[t]{2}{*}{4} & OrNV4 F & 5'-ACT ACC AGT CGA ACG AAG TAT TG-3' & 43.5 & 1498 \\
\hline & OrNV4 R & 5'-TAG CTT GTC GGT CAG TGA AAC-3' & 47.6 & \\
\hline \multirow[t]{2}{*}{5} & OrNV200 F & 5'-CGC ATA CTG CAA TAC GTA CAC-3' & 47.6 & 666 \\
\hline & OrNV200 R & 5'-CTA AAT TCC CAG GTC TGC AAA C-3' & 45.5 & \\
\hline
\end{tabular}


Table 4. Five running tests between isolate using DnaSP program to investigate OrNV variability. Isolate groups were determined based on phylogenetic tree results (Figure 1)

\begin{tabular}{lcccccc}
\hline OrNV isolate & $\begin{array}{c}\text { Variable } \\
\text { sites (s) }\end{array}$ & $\begin{array}{c}\text { Number of } \\
\text { mutation } \\
\text { (Eta) }\end{array}$ & $\begin{array}{c}\text { Nucleotide } \\
\text { diversity } \\
(\text { Pi) }\end{array}$ & $\begin{array}{c}\text { Haplotype } \\
\text { (gene) } \\
\text { diversity (Hd) }\end{array}$ & $\begin{array}{c}\text { Fu and Li's D } \\
\text { test }\end{array}$ & $\begin{array}{c}\text { Fu and Li's F } \\
\text { test }\end{array}$ \\
\hline Sulbar01, Jateng01, Kalteng01 & 86 & 88 & 0.01553 & 1.00 & 0.00 (statistical & 0.00 (statistical \\
& & & & & significance) & significance) \\
Belitung01, Jabar01 & 13 & 13 & 0.00347 & 1.00 & 0.00 & 0.00 \\
Sumut01, Sulteng01 & 3 & 3 & 0.00080 & 1.00 & 0.00 & 0.00 \\
Sulteng01, Riau01 & 0 & 0 & 0.00 & - & 0.00 & 0.00 \\
Riau01, Kaltim01 & 2 & 2 & 0.00053 & 1.00 & 0.00 & 0.00 \\
\hline
\end{tabular}

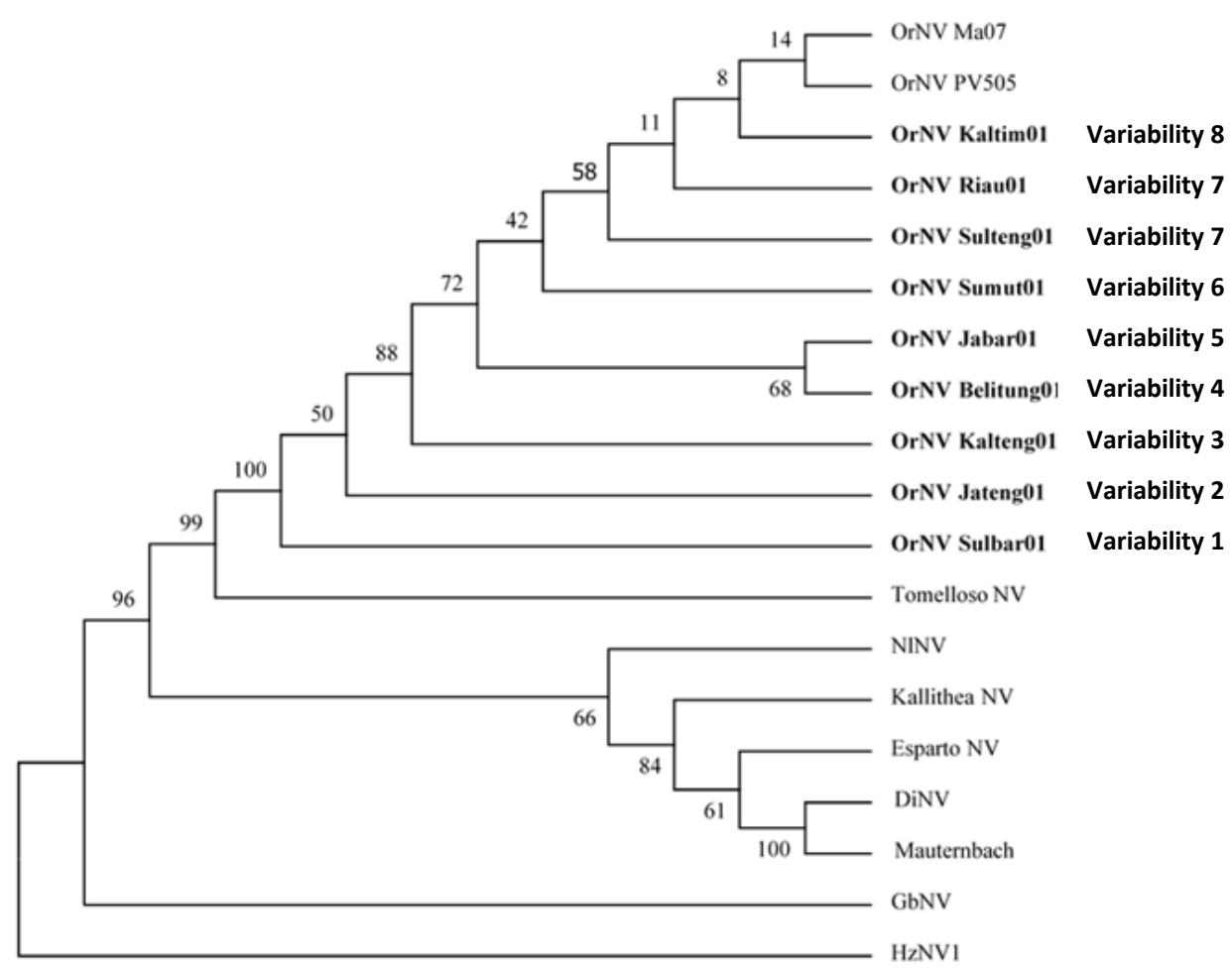

Figure 1. Maximum likelihood phylogenetic based on DNA polymerase gene of Indonesian Oryctes rhinoceros Nudivirus (OrNV) (write in bold words) and recent National Center for Biotechnology Information (NCBI) deposited of Genus Alphanudivirus. Percent bootstrap values with 1000 replications were listed for each node.

$\mathrm{Fu}$ and $\mathrm{Li}$ test both $\mathrm{D}$ and $\mathrm{F}$ are calculating the distribution of alleles or haplotypes under the assumption of neutrality of mutation ( $\mathrm{Fu}$ and $\mathrm{Li} 1993)$. The result for $\mathrm{Fu}$ and Li's D and F tests in Table 4 were all statistical significance. The $\mathrm{Fu}$ and $\mathrm{Li}$ test score was not negative which indicated that the OrNV population in neutral evolution (de Jong et al 2011). The rate of sequence DNA changes almost like living fossils whose morphological characters hardly to change. Sequences of DNA is genetic information transmitted from generation to generation (Ohta 1992). In neutral theory of evolution, evolution is a consequence of two processes genetic variability generated by mutation and changes of alleles frequency withinpopulation over time. These mutations are not deleterious but its rapidly removed by natural selection. A neutral mutation is one that does not affect an organism's ability to survive and reproduce. In other words, the mutation is not deleterious but in neutral rather than beneficial. Allelic frequencies may change simply as random gamete sampling in reproduction process. This process is called genetic drift. Genetic drift could lead to fixation of some alleles or loss of the others. Gene duplication may get fixed in population by random genetic drift because they are not deleterious. The neutral theory suggests that a mutant gene can arise within a population and reach fixation by chance, rather by selective advantage. Most evolution changes at molecular level are due to selectively neutral (Duret 2008). Although Sulteng01 and Riau01 were supposed low level of nucleotide diversity, both isolates faced neutral evolution based on Fu \% Li's D and F test. 


\section{OrNV epizootiology}

Insect epizootiology is science of causes and form of mass phenomena of diseases at all levels of intensity in an animal host population (Vega and Kaya 1993). Definition that explains the epizootiology term is epizootic and enzootic. Epizootic refers to unusual large number of diseases cases in host population, while enzootic is low prevalence and is constantly present of the diseases in the host population. OrNV spread in its host population, the $O$. rhinoceros, are influenced by their pathogenicity and transmissibility. The transmission pathways by the OrNV must ensure their survival in its host. They infect host but are only a non-lethal infection. This OrNV transmitted by horizontal normal route from host to host, and vertical transmission from parent to offspring (Vega and Kaya 1993). Non-lethal transmitted OrNV disease may be dispersed in various $O$. rhinoceros populations in Indonesia.

Nucleotide diversity $(\mathrm{Pi})$ score of isolate Sulbar01, Jateng01, Kalteng01 were 0.01553 and Pi score of isolate Belitung01 and Jabar01 was 0.00347. These two Pi values were classified as high score. Pi score of isolate Sumut01 and Sulteng01 were 0.0080 , Sulteng01 and Riau01 were 0.00000 , while isolate Riau01 and Kaltim01 were 0.00053 (Table 4). These two Pi values were classified as low scores (de Jong et al 2011). High score of Pi have correlated with value of variable sites (S), number of mutation (Eta) that also showed high points. High score of nucleotide diversity, variable sites, and number of mutations are typically considered a function of population history and the initial origin of the OrNV. Long period of
OrNV existence, means a long time for mutation accumulation and hence increased level of nucleotide diversity. The occurrence of a bottleneck in population size, accompanying with dispersion of OrNV to other locations would further increase genetic drift, which reduced genetic variation (Relethford 2015).

Initial origin of the OrNV comes from West Sulawesi (isolate Sulbar01), non-lethal infected host $O$. rhinoceros than headed to Central Java (isolate Jateng01). Some nonlethal infected of host then fly from Central Java to Central Kalimantan (isolate Kalteng01), to Belitung (isolate Belitung01) and to West Java (isolate Jabar01) (Figure 2). These dispersion routes were not at long distances. Nudivirus ancestor supposed to appear at $310 \mathrm{Mya}$, in Paleozoic era in the Carboniferous period, suggesting that they already infected the first insects which appeared during Devonian and Carboniferous period (Theze et al. 2011). The emergence of Kalimantan, Java, and Sulawesi island was relatively new compared to the emergence of Nudivirus ancestral. These islands had been formed in Miocene Era 20 Mya until early Pliocene 5 Mya. Central Kalimantan, the north part of Central Java, almost all region of West Java was part of land in Sundaland paleogeography, while West Sulawesi was first appeared land in Wallacean paleogeography (Hall 2013). It had been estimated that OrNV ancestral arrived on those first appeared land and continues to regenerate until now. The mutation site in DNA polymerase gene accumulated which amounts to 88 in West Sulawesi, Central Java and Central Kalimantan OrNV populations, and 13 mutations site of OrNV populations from Belitung and West Java.

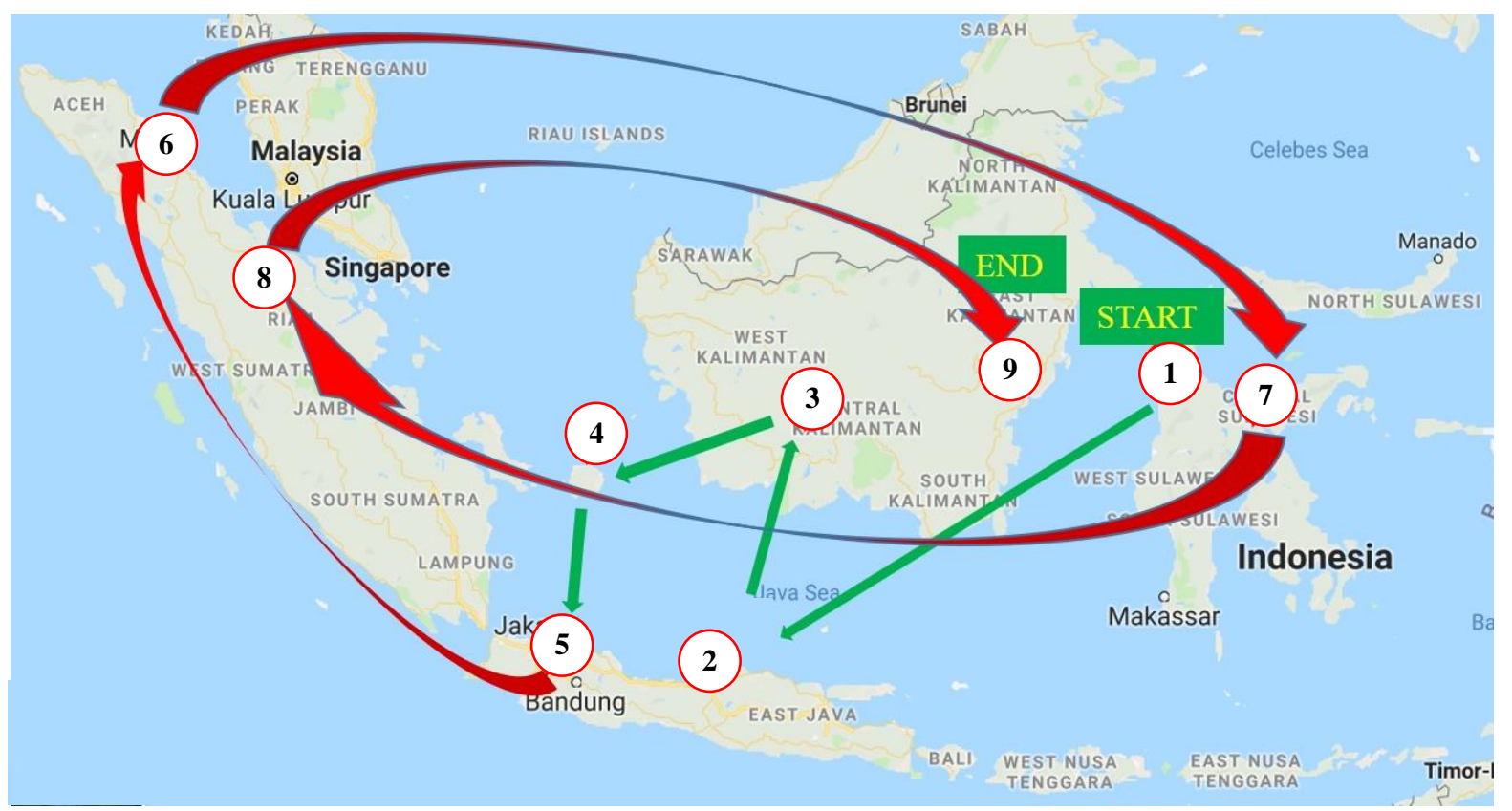

Figure 2. The epizootiology dispersion pattern of Indonesian OrNV starts from (1) West Sulawesi which spread to (2) Central Java, then to (3) Central Kalimantan, to (4) Belitung and to (5) West Java. These consecutive four isolates have high score of nucleotide diversity. Route of the epizootiology of OrNV began to spread across the island from (5) West Java to (6) North Sumatra, then to (7) Central Sulawesi to (8) Riau province and ended in (9) East Kalimantan. OrNV which experiences cross-island travel has low Nucleotide diversity as shown in Table 3. 
OrNV with non-lethal infection to its host from old ancestry then disperse across the island with relatively long distance. The OrNV from West Java (isolate Jabar01) disperses to North Sumatra (isolate Sumut01), then to Central Sulawesi (isolate Sulteng01), to Riau province (isolate Riau01) and to East Kalimantan (isolate Kaltim01). This long-distance of OrNV dispersion was probably as a result of oil palm plantation development in Indonesia. Oil palms have been cultivated since 1911 in Sumatra, and 1981 in Kalimantan. Sumatra and Kalimantan become production center of Indonesian oil palm (Pamin 1998). Oil palm plantation began to be expanded to Central Sulawesi and West Sulawesi in 2004 (Fatmasari et al. 2018). Sulawesi island is not a major oil palm plantation as Sumatra and Kalimantan islands, areas under oil-palm cultivation are only 354,000 ha. Java island is also not intensively cultivated with oil palms, the area occupied by oil palm as only 36,163 ha in Banten province (Gapki, 2015; Directorate General of Estate Crop RI 2016).

The advantage of OrNV epizootiology dispersion information related to the next OrNV's virulence test, that could be explored between high and low nucleotide diversity of isolates. Isolates with high genetic variability were Sulbar01, Jateng01, Kalteng01, Belitung01, Jabar01 and isolate with low genetic variability were Sumut01, Sulteng01, Riau01, and Kaltim01. We could choose two strategies to manage $O$. rhinoceros by selecting high virulence or low virulence of the isolate. High virulence is needed to control $O$. rhinoceros population as quickly as possible. Once an OrNV application is applied, the $O$. rhinoceros population will be reduced immediately. This condition is requested if $O$. rhinoceros population on highly conditioning as devastating pest. Current status of $O$. rhinoceros is main pest of coconut and oil palm (Bedford 2014). Mild virulence of OrNV isolate is requested to manage $O$. rhinoceros population under economic threshold. By this research, it is supposed that OrNV from Java and Belitung island consists of only high nucleotide diversity. Sumatra island supposed consists only OrNV with low nucleotide diversity, while Kalimantan and Sulawesi island consist mixture of low and high nucleotide diversity. Crawford and Zelazny (1990) detected three types of genomic changes of OrNV isolate that had been released in Maldives Island after four years. It was supposed after 109 years of oil palm plantation in Sumatra island (Pamin et al. 2018) and the genetic drift changed the old population of OrNV with young populations that have low nucleotide diversity. Oil palm development in Kalimantan and Sulawesi island is relatively new (39 years and 16 years) so that it still found both young and old OrNV populations.

\section{Relationship of OrNV with other Alphanudivirus}

Since developed into a new family (Jehle et al. 2013), the discovery of Nudiviridae members has been increasing. Jehle et al. (2013) reported GbNV (Orthoptera order), OrNV (Coleoptera order) as a member of Genus Alphanudivirus and HzNV 1, HzNV 2 (Lepidoptera order) as a member of genus Betanudivirus. The following year,
Bézier et al. (2015) added PmNV (Decapoda order) and ToNV (Diptera order) as members of the new genus Gammanudivirus. The discovery of Homarus gammarus nudivirus (HgNV) by Holt et al. (2019) therefore suggested ToNV as a separate genus, Deltanudivirus, while Gammanudivirus had $\mathrm{HgNV}$ and PmNV as members. The Gammanudivirus genus was proposed as a specialized member group of Nudiviridae that infects aquatic crustaceans (Holt et al. 2019).

Some genes are visibly better than others to build evolutionary relationship among taxa at particular level of divergence. DNA sequences data could better understand the way genes and species evolved (Simon et al 1994). Viruses lack universal genes that all viruses could be placed in unified phylogeny (Simmonds et al 2017). Even though, DNA polymerase has been shown distinct phylogenetic of DNA viruses of Genus Alphanudivirus as presented in Figure 1. Phylogenetic tree constructed by Hill and Unckless (2018) using Nudiviral 20 conserves ORF resulted in similar phylogenetic pattern with Figure 1.

The Alphanudivirus has grown and now have eight species: (i) Oryctes rhinoceros nudivirus (OrNV); (ii) Tomelloso nudivirus; (iii) Drosophila innubila nudivirus (DiNV); (iv) Mauternbach Nudivirus; (v) Kallithea nudivirus; (vi) Esparto nudivirus; (vii) Nilaparvata lugens endogenous nudivirus (N1NV); (viii) Gryllus bimaculatus nudivirus (GbNV). The host of these genera: Orthoptera (GbNV); Hemiptera (NINV); Diptera (DiNV, Tomelloso NV, Mauternbach NV, Kallithea NV, Esparto NV); and Coleoptera (OrNV). OrNV closely related to Tomolloso Nudivirus. Mauternbach Nudivirus, DiNV, Esparto Nudivirus, and Kallithea Nudivirus clustered together have the same host, Drosophila sp. (Diptera: Drosophilidae) (Webster et al. 2015). These clustered taxa were a sister group of the OrNV and Tomelloso Nudivirus. Tomelloso Nudivirus also has Drosophila sp. as its host but is closely related to OrNV. GbNV has been described as taxa from the earliest branch of Alphanudivirus phylogenetic tree (Wang et al. 2007c) and this matches our study (Figure 1).

Palmer et al. (2019) also reported the phylogenetic of 8 species of Genus Alphanudivirus using maximum likelihood method of DNA polymerase protein. This tree pattern was similar to Figure 1 as presented above, except the position of the species NINV out of the cluster: Mauternbach Nudivirus, DiNV, Esparto Nudivirus, Kallithea Nudivirus. The NINV displacement in phylogenetic tree supposed because other species of Alphanudivirus have not yet been found. With more members of a cluster founded, the phylogenetic tree pattern became stable (Pellock 1996). Investigated using Fu and $\mathrm{Li}$ test both D and F represent negative scores for cluster with NINV or without NINV. Negative score of Fu and Li score indicate that this cluster stands on non-neutrality evolution. The evolution of organisms supposed to be in neutral condition as presented with statistical test significant $(\mathrm{Fu}$ and $\mathrm{Li}$ 1993).

Nudivirus has been infected with diverse arthropods hosts suggesting their ancient origin and complex evolutionary history. Nudivirus infect early 
hemimetabolous Orthoptera to the most recent emerged holometabolous Lepidoptera. Nudivius also present in marine crustacean hosts (Wang and Jehle 2009). Order infected by this Alphanudivirus i.e. Orthoptera, Coleoptera, Hemiptera, Diptera. Although phylogenetic patterns of its host different from Alphanudivirus pattern but they have resemblance of immature life cycle niche. All members correlated with soil as a habitat during immature. This shared ecological niche may explain their closely related taxa. Phylogenetic incongruence between virus and their insect hosts suggests that host ecology rather than host phylogeny was the driving force of virus evolution (Wang et al. 2007c).

Insect and crustacean lineages associated with dsDNA viruses appeared in middle of Paleozoic Era at 310 Mya (Theze et al. 2011). Nudivirus ancestor with its sister families diverged at late Carboniferous as well as the insect was diversifying into new order. Unfortunately, their evolution way was independent, lack of co-phylogeny. It was supposed that viruses may have colonized new insect and crustacean hosts many times. Nudivirus ancestor lack of occlusion bodies as environment protectant. It has been proposed that evolution association with their host involving viral persistence or latency. Ancestral insect becomes main resources for ancestral Nudivirus survival. When new insect species evolved, virus individual adapted to that new ancestral host. The ecological speciation mechanism at some point produced new virus species as the Alphanudivirus genus have the same immature soil niche.

In conclusion, nive of OrNV isolates collected from the research were found eight haplotypes with two kinds of high and low genetic diversity. These genetic diversities supposed to correlate with development of oil palm plantation and genetic drift. OrNV epizootiology of old population with high genetic diversity starts from West Sulawesi to Central Java, to Central Kalimantan, to Belitung Island, and to West Java. Epizootiology then continued from West Java to North Sumatra, to Central Sulawesi, to Riau, to East Kalimantan with its properties were low genetic diversity. Java and Belitung were sources sites of old OrNV population, otherwise Sumatra as sources site of new OrNV population. Kalimantan and Sulawesi were found of mixed populations both old and new OrNV. This OrNV belongs to Genus Alphanudivirus where the closeness of each member was based on immature ecological niche.

\section{REFERENCES}

Abidin C, Ahmad A, Salim H, Hamid N. 2014. Population dynamics of Oryctes rhinoceros in decomposing oil palm trunks in areas practicing zero burning and partial burning. J Oil Palm Res 26: 140145.

Bedford GO. 2014. Advances in the control of rhinoceros beetle, Oryctes rhinoceros in oil palm. J Oil Palm Res 26: 183-194.

Bèzier A, Thézé J, Gavory F, Gaillard J, Poulain J, Drezen JM, Herniou EA. 2015. The genome of the nucleopolyhedrosis-causing virus from Tipula oleracea sheds new light on the Nudiviridae Family. J Virol 89: 3008-3025.

Black JL, Lorenz GM, Faske TR, Popham HJR, Daddock KJ, Bateman NR, Seiter NJ. 2019. Field studies on the horizontal transmission potential by voluntary and involuntary carriers of Helicoverpa armigera necleopolyhedrovirus (Baculoviridae). J Econ Entomol 112 (3): 1098-1104. DOI: 10.1093/jee/toz012.

Braithwaite DK, Ito J. 1993. Compilation, alignment, and phylogenetic relationships of DNA polymerases. Nucleic Acids Res 21: 787-802.

Choi KH. 2012. Viral polymerases. Adv Exp Med Biol 726: 267-304. DOI: 10.1007/978-1-4614-0980-9_12

Cory JS, Myers JH. 2003. The ecology and evolution of insect baculovirus. Ann Rev Ecol Evol Syst 34: 239-372. DOI: 10.1146/annurev.ecolsys.34.011802.132402.

Crawford AM, Zelazny B. 1990. Evolution of Oryctes baculovirus: rate and types of genomic change. Virology 174: 294-298.

de Jong MA, Wahlberg N, van Eijk M, Brakefield PM, Zwaan BJ. 2011. Mitochondrial DNA signature for range-wide populations of Bicyelus anynana suggests a rapid expansion from recent refugia. PloS One 6 (6): e21385. DOI: 10.13711/journal.pone.0021385

Directorate General of Estate Crops RI (2016). Oil Palm in Statistics of Plantation Crop from 2015-2017. Directorate General of Estate Crops, Jakarta.

Duret L. 2008. Neutral theory. The null hypothesis of molecular evolution. Nat Educat 1 (1): 218.

Esser KH, Marx WH, Lisowsky T. 2005. Nucleic acid-free matrix: Regeneration of DNA binding columns. Biotechniques 39: 270-271.

Federici BA, Bigot Y. 2003. Origin and evolution of polydnaviruses by symbiogenesis of insect DNA viruses in endoparasitic wasps. J Insect Physiol 49: 419-432.

Federici BA, Maddox JV. 1996. Host specificity in microbe-insect interactions: insect control by bacterial, fungal, and viral pathogens. BioScience 46 (6): 410-421.

Fu Y-X and Li W-H. 1993. Statistical tests of neutrality of mutation. Genetics 133: 693-709.

GAPKI [Indonesian Association of Oil Palm Entrepreneurs]. 2015.. Myth 704 Oil Palm Plantation as Deforestation Trigger in Sulawesi. GAPKI, Jakarta. https: //gapki.id/news/5932/mitos-7-05-kebun-sawitpemicu-utama-konversihutan-menjadi-non-hutan-sulawesi\# [7 April 2020]. [Indonesian]

Hall JD, Coen DM, Fisher BL, Weisslitz, Randall S, Almy RE, Gelep PT, Schaffer PA. 1984. Generation of genetic diversity in Herpes simplex virus: an antimutator phenotype maps to the DNA polymerase locus. Virology 132: 26-27.

Hall R. 2013. The paleogeography of Sundaland and Wallacea since the $\begin{array}{lllll}\text { late Jurassic. J Limnol } 72 & \text { (s2): 1-17. DOI: }\end{array}$ 10.4081/jlimnol.2013.s2.e1.

Hall TA. 1999. BioEdit: a user-friendly biological sequence alignment editor and analysis program for Windows 95/98/NT. Nucleic Acids Symp Ser 41: 95-98.

Hill T, Unckless RL. 2018. The dynamic evolution of Drosophila innubila nudivirus. Infect Genet Evol 57: 151-157.

Holt CC, Stone M, Bass D, Batemana KS, Aerlea R van, Daniels CL, Giezen M van der, Ross S, Hooper C, Stentiforda, GD. 2019. The first clawed lobster virus Homarus gammarus nudivirus (HgNV n. sp.) expands the diversity of the Nudiviridae. Sci Rep 9: 10086. DOI: 10.1038/s41598-019-46008-y

Huger AM, Krieg A. 1991. Atlas of Invertebrate Viruses. CRC Press, New York.

Huger AM. 1966. A virus disease of the Indian rhinoceros beetles, Oryctes rhinoceros (Linnaeus), caused by a new type of insect virus, Rhabdionvirus oryctes gen n, sp n. J Invertebr Pathol 8: 38-51.

Huger AM. 2005. The Oryctes virus: its detection, identification, and implementation in biological control of the coconut palm rhinoceros beetle, Oryctes rhinoceros (Coleoptera: Scarabaeidae). J Invertebr Pathol 89: 78-84.

Jackson T, Lal SN, Tuuapola K, Prasad S, Monk J, Richards N, Marshall S. 2010. Biological control of rhinoceros beetles in the pacific using Oryctes virus. Operation Protocols. Lincoln Research Centre, New Zealand.

Jehle JA, Burand J, Herniou E, Herniou Elisabeth, Harrison R, Arif B, Oers M Van, Becnel J. 2013. Creation of a new family Nudivirus including two new genera and three species. ICTV Proposal with Number 2013.003a-kl 1-29.

Kobayashi J, Somowiyarjo S. 1995. Properties of Oryctes baculovirus isolated in Indonesia. J Perlindungan Tanam Indones 1 (1): 41-46.

Kumar S, Stecher G, Tamura K. 2016. MEGA7: Molecular evolutionary genetics analysis version 7.0 for bigger datasets. Mol Biol Evol 33: 1870-1874. 
Moslim R, Ghani I, Wahid MB, Glare TR, Jackson TA, 2010. Optimization of the polymerase chain reaction (PCR) method for the detection of Oryctes rhinoceros virus. J Oil Palm Res 22: 736-749.

Moslim R, Kamarudin N, Ghani IA, Wahid MB, Jackson TA, Tey CC, Ahdly AM. 2011. Molecular approaches in the assessment of Oryctes rhinoceros virus for the control of rhinoceros beetle in oil palm plantations. J Oil Palm Res 23: 1096-1109.

Nature. 2005. A haplotype map of the human genome. Nature 437 (7063): 1299-1320.

Nei M, Kumar S. 2000. Molecular Evolution and Phylogenetic. Oxford Univ Press, New York

Ohta T. 1992. The nearly neutral theory of molecular evolution. Annu Rev Ecol Syst 23: 263-286.

Palmer WH, Joosten J, Overheul GJ, Jansen PW, Vermeulen M, Obbard DJ, Van Rij RP. 2019. Induction and suppression of NF- $\kappa \mathrm{B}$ signalling by a DNA virus of Drosophila. J Virol 93: e01443-18. DOI: 10.1128/JVI .01443-18

Pamin K.1998. A hundred and fifty years of oil palm development in Indonesia from the Bogor botanical garden to the industry. Proceeding International Oil Palm Conference, Nusa Dua, Bali, September 23-25.

Pellock BJ, Lu A, Meagher RB, Weise MJ, Miller LK. 1996. Sequence, function, and phylogenetic analysis of an ascovirus DNA polymerase gene. Virology 216: 146-157.

Ramle M, Wahid MB, Norman K, Glare TR, Jackson TA. 2005. The incidence and use of Oryctes virus for control of rhinoceros beetle in oil palm plantations in Malaysia. J Invertebr Pathol 89: 85-90.

Relethford JH. 2015. Chapter 15. Contemporary human genetic variation. In: Basic in Human Evolution. Academic Press, New York. DOI: 10.1016/C2014-0-02208-3.

Richards NK, Glare TR, Aloali'I I, Jackson TA. 1999. Primers for the detection of Oryctes virus from Scarabaeidae (Coleoptera). Mol Ecol 8: 1551-1561.

Rozas J, Ferrer-Mata A, Sanchez-DelBarrio JC, Guirao-Rico S, Librado P, Ramos-Onsins SE, Sanchez-Gracia A. 2017. DnaSP V6: DNA sequence polymorphism analysis of large datasets. Mol Biol Evol 34: 3299-3302.

Salim, Hosang ML. 2013. Serangan Oryctes rhinoceros pada kelapa kopyor di beberapa sentra produksi dan potensi Metarhizium anisopliae sebagai musuh alami. Bul Palma 14: 47-53. [Indonesian]

Shackelton LA, Holmes EC. 2004. The evolution of large DNA viruses: combining genomic information of viruses and their hosts. Trends Microbiol 12: 458-465.
Simmonds P, Adams MJ, Benkő M, Breitbart M, Brister JR, Carstens EB, Davison AJ, Delwart E, Gorbalenya AE, Harrach B, Hull R, King AMQ, Koonin EV, Krupovic M, Kuhn JH, Lefkowitz EJ, Nibert ML, Orton R, Roossinck MJ, Sabanadzovic S, Sullivan MB, Suttle CA, Tesh RB, van der Vlugt RA, Varsani A, Zerbini FM. 2017. Virus taxonomy in the age of metagenomics. Nat Rev Microbiol 15: 161168. DOI: $10.1038 /$ nrmicro.2016.177

Simon C, Frati F, Beckenbach A, Crespi B, Liu H, Flook P. 1994 Evolution, weighting, and phylogenetic utility of mitochondrial gene sequences and a compilation of conserved polymerase chain reaction primers. Ann Entomol Soc Am 87: 651-701.

Sutrisno H. 2006. Evolution of a wingless gene and its utility for inferring the relationships within glyphodes moths. Hayati J Biosci 13: 145150.

Tan SC, Yiap BC. 2009. DNA, RNA, and protein extraction: the past and the present. J Biomed Biotechnol 2009: 574398. DOI: $10.1155 / 2009 / 574398$.

Theze J, Bezier A, Periquet G, Drezen JM, Herniou EA. 2011. Paleozoic origin of insect large dsDNA viruses. PNAS 108 (38): 15931-15935. DOI: 10.1073/pnas.IL05580108/-/DCSupplemental.

Thompson J, Gibson T, Plewniak F, Jeanmougin F, Higgins D. 1997. The CLUSTAL_X windows interface: flexible strategies for multiple sequence alignment aided by quality analysis tools. Nucleic Acids Res 25: 4876-4882.

Vega FE, Kaya HK. 1993. Insect Pathology, 2nd ed. Academic Press, California

Wang Y, Burand J, Jehle JA. 2007c. Nudivirus genomics: diversity and classification. Virol Sin 22: 128-136.

Wang Y, Jehle JA. 2009. Nudiviruses and other large, double-stranded circular DNA viruses of invertebrates: New insights on an old topic. J Invert Pathol 101: 187-193.

Wang Y, Kleespies RG, Huger AM, Jehle JA. 2007a. The Genome of Gryllus bimaculatus nudivirus indicates an ancient diversification of baculovirus-related nonoccluded nudiviruses of insects. J Virol 81: 5395-5406.

Wang Y, Van Oers MM, Crawford AM, Vlak JM, Jehle JA. 2007b. Genomic analysis of Oryctes rhinoceros virus reveals genetic relatedness to Heliothis zea virus 1. Arch. Virol 152: 519-531.

Webster CL, Waldron FM, Robertson S, Crowson D, Ferrari G, Quintana JF, Brouqui JM, Bayne EH, Longdon B, Buck AH, Lazzaro BP, Akorli J, Haddrill PR, Obbard DJ. 2015. The discovery, distribution, and evolution of viruses associated with Drosophila melanogaster. PLoS Biol 13 (7): e1002210. DOI: 10.1371/journal.pbio.1002210.

Wolf YI, Rogozin IB, Grishin NV, Koonin EV. 2002. Genome trees and the tree of life. Trends Genet 18: 472-479. 